\title{
Investigating High School Students' Attitudes Towards, Beliefs about and Behaviors Associated with Water and Energy Saving
}

\author{
Osman Çimen $^{1, *}$, Mehmet Yılmaz ${ }^{1} \&$ Merve Çolak $^{1}$ \\ ${ }^{1}$ Department of Biology Education, Faculty of Gazi Education, Gazi University, Ankara, \\ Turkey \\ *Correspondence: Department of Biology Education, Faculty of Gazi Education, Gazi \\ University, Ankara, Turkey. E-mail: osman.cimen@gmail.com
}

Received: April 25, 2016 Accepted: May 23, 2016 Published: June 23, 2016

doi:10.5296/ije.v8i2.9375 URL: http://dx.doi.org/10.5296/ije.v8i2.9375

\begin{abstract}
Schools play a critical role in raising awareness in students of the importance of water conservation and environmental protection. Based on this premise, the current study aims to investigate high school students' attitudes towards, beliefs about and behaviors associated with water and energy saving. The research was designed as survey model and involved a study group consisting of 102 high school students who attended schools in Ankara, Turkey during the 2014 Spring Semester. The Water and Energy Saving Attitude, Belief, and Behavior Scale, which was developed by this study's researchers, was used as the data collection tool. The data obtained were analyzed with t-test, ANOVA and Pearson correlation, using the SPSS 20 software package. Results from the research showed that high school students' beliefs about water and energy saving significantly differed according to gender, grade level, the presence of an environmentally aware family member and concern levels toward the environment, and that the students' attitudes significantly differed in terms of the presence of an environmentally aware family member and concern level towards the environment. No significant relationship was found, however, between the high school students' behaviors and attitudes towards water and energy saving and between their behaviors and beliefs, while a mid-level significant relationship was determined between high school students' beliefs and attitudes.
\end{abstract}

Keywords: water and energy problem, water and energy saving, attitude, behaviors, beliefs. 


\section{Introduction}

Today, concerns about the environment occupy the minds of many and stand atop the agenda of governments around the world. Environment may be defined as the physical, biological, social, economic, and cultural medium wherein life-long interactions between people and other living organisms are fostered and their relationships sustained (Algul, 2004). The living, dynamic environment faces many threats to its existence, such as global warming, destruction of bio-diversity, diminishing natural resources and not least of all, problems related to water and energy conservation.

The rise in water and energy use has, as of recently, been among the top issues attracting attention and garnering widespread discussion throughout the world. As the demand for energy and water continues to be on an upward trend due to industrialization, urbanization and social enrichment, the provision of water and energy resources to sustain basic human life has gradually begun to diminish as a result of unsustainable consumption (Aydiner, Boylu and Yertutan, 2012).

Researchers predict that today's global population of 6.8 billion will increase to 8.3 billion by 2030. In other words, the global population is expected to experience a growth of 1.5 billion people (Population Institute, 2013). This increase in population will trigger a global need for food and additional competition for land, water and energy (Godfray et al., 2010).

Water scarcity has resulted from the recent growth in population, industrialization, pollution of limited water resources and the negative impact of changing climate conditions on water resources (Turan and Eren, 2008). With the rapid growth in population, water consumption around the world is estimated to rise to $3800 \mathrm{~km}^{3}$ annually by 2025 (Jury and Vaux, 2005). The growing population will require more water for drinking, hygiene food production and industrial purposes (Rogers, 2008).

Humankind's reliance on rich fossil deposits is a feature of modern society, one that in turn has led to the world's over-dependence on these resources for industrial development, food provision and economic growth. Today, a large majority $(85 \%)$ of the energy used for industrial and domestic purposes is based on fossil fuels, such as coal and oil. These fossil fuels are used in many areas of life, including daily consumed products, industrial chemicals, asphalt production, clothes and cosmetics, to name several (EIA, 2009). As the increase in energy use fuels the growth in demand for fossil fuels, the rise in the global population has increased the energy consumption per person within the last 40 years (UNEP, 2002).

In 2011, the amount of $\mathrm{CO}_{2}$ resulting from electricity consumption was 5700 million tons (Weber and Matthews, 2007). By applying simple saving techniques, such as lowering the water thermostat and leaving computers in sleep mode, $\mathrm{CO}_{2}$ emissions and greenhouse gases can be reduced (Mankof et al., 2010). Hansen (2009) stated that the major reason for the environmental problem of climate change can be attributed to the emission of greenhouse gases in the atmosphere. Energy saving has the added benefit of reducing the pollution generated from extracting energy resources (Hancher and Jansen, 2004).

Education is of vital importance in preparing upcoming generations to solve environmental 
problems. Environmental education in particular is a process whereby individuals are provided with information about their environment, taught awareness, values and skills, and enjoined to act decisively in order to solve environmental issues (Dogan, 1997). In order to rectify the damage done to the environment, it is key that individuals exhibit sensitive behavior towards the environment, particularly in regards to water and energy saving.

A review of the related literature shows that included among the studies conducted on water saving are those that have focused on the relationship between students' water saving behavior and their knowledge level (Aijami, 2008), as well as the demographic variables, such as gender and age, impacting this relationship (Alaş et al, 2009; Demir, 2009; Barrow and Morrisey, 1987; Lawrenz and Dantchik, 1985; Clewell and Cambell, 2002), on the development of a water saving scale (Çankaya and Çelik İşcan, 2014) and finally, on the effectiveness of water saving education programs (Engin et al., 2009; Corral-Verdugo, 2002).

It can be observed that a large portion of the research conducted on this particular subject of energy has focused on students' knowledge and awareness levels associated with energy (Attari et al., 2010; Curry et al., 2007; Gardner and Stern, 2008). Gambro and Switzky (1999), for example, stated in their study that high school students' levels of environmental knowledge tended to increase as their grade levels rose. Barrow and Morrisey (1989) found that high school students' energy literacy levels were generally low, but that female students' energy literacy levels were higher than those of male students. In contrast, Dewaters and Powers (2010) showed in their research that a majority of students had high levels of awareness in relation to energy issues. And finally, Lawrenz (1983) found that students' levels of energy knowledge differed significantly according to gender, in favor of males.

As the increase in water and energy consumption reduces the limited natural resources, in order to leave sustainable water and energy sources for future generations, each and every member of society, but first and foremost students, must practice responsible water and energy saving behaviour. The current study, therefore, aims to investigate high school students' attitudes and behaviors toward and beliefs about water and energy saving in terms of various variables. The following questions were put forward for the purposes of the current research:

Do high school students' attitudes and behaviors toward and beliefs about water and energy saving significantly differ according to gender, grade level, membership in environmental clubs, family awareness of the environment, subscription to periodicals about the environment and level of concern about the environment?

Does a significant relationship exist between high school students' attitudes and behaviors toward and beliefs about water and energy saving?

\section{Methods}

\subsection{Research Model}

The current research was designed as a descriptive field study under a survey model. A survey model is an appropriate research model for describing a past or present phenomenon 
as it actually was or is (Karasar, 1999).

\subsection{Study Group}

The study group consisted of 101 students who attended either of two Anadolu High Schools in Ankara during the 2013-2014 academic year. Males constituted 47\% of the study's students and females $53 \%$. In terms of grade levels, $25 \%$ of the students were in the $9^{\text {th }}$ grade, $46 \%$ in the $10^{\text {th }}$ grade and $21 \%$ in the $11^{\text {th }}$ grade.

\subsection{Data Collection Tools}

The Water and Energy Saving Attitude, Behavior and Belief Scale, developed by this study's researchers, was used as the data collection tool in the current study. The scale consists of three sub-scales: water and energy attitudes, water and energy behaviors and water and energy beliefs. During the scale development process, a group of 40 high school students were asked open-ended questions that had been formulated following a review of the related literature. Items were created through the analysis of responses to open-ended questions, and a pool of questions was developed out of those items and other items obtained from the literature review. A draft scale was then designed through the selection of items from the pool under expert supervision. A Turkish language expert performed a review of the draft scale in terms of its grammar and understandability. The draft scale consisted of a total of 51 items, with 18 of those items falling under the sub-scale of attitude, 16 under the sub-scale of behavior and 17 under the sub-scale of belief. After the completion of validity and reliability analyses, the Water and Energy Saving Attitude, Behavior and Belief Scale took its final shape. On the finalized scale, the 13-item attitude sub-scale had a Cronbach's alpha of .70; the 11-item behavior sub-scale had a Cronbach's alpha of .76; and the 14-item belief sub-scale had a Cronbach's alpha of .71. The Attitude and Belief sub-scales featured 5-point Likert scales, with options of "Strongly Disagree", "Disagree", "Neutral", "Agree", and "Strongly Agree". The Behavior sub-scale, on the other hand, was a 5-degree type scale, with options of "Never", "Rarely", "Sometimes", "Usually", and "Always".

\subsection{Data Analysis}

Research data were analyzed using SPSS 18 package software to conduct t-test, ANOVA and Pearson's Correlation.

\section{Findings}

The findings related to the sub-question on whether high school students' attitudes and behaviors toward and beliefs about water and energy saving significantly differed according to gender, grade level, membership in environmental clubs, family awareness of the environment, subscription to periodicals about the environment and level of concern about the environment are presented below.

Table 1 below presents the descriptive findings regarding the high school students' water and energy saving attitudes, behaviors and beliefs scores. 
Table 1. Descriptive findings associated with high school students' water and energy saving attitudes, behaviors and beliefs scores

\begin{tabular}{llllll}
\hline & $\mathrm{N}$ & Lowest & Highest & $\overline{\mathrm{x}}$ & SS \\
\hline Attitude & 101 & 27.00 & 61.00 & 44.25 & 7.23 \\
Behavior & 100 & 19.00 & 55.00 & 35.83 & 6.98 \\
Belief & 101 & 30.00 & 68.00 & 52.88 & 7.61 \\
\hline
\end{tabular}

Table 1 shows that the high school students' water and energy saving average scores under attitude were $\bar{x}=44.25, \bar{x}=35.83$ under behavior and $\bar{x}=52.88$ under belief. When considering the lowest and the highest scores on the sub-scales, the students' attitudes toward water and energy saving were observed to be at high levels, their behaviors at mid-to-high levels and their beliefs at high-to-very-high levels.

Table 2 below presents the t-test results regarding high school students' water and energy saving attitudes, behaviors and beliefs in terms of gender.

Table 2. T-test results associated with high school students' water and energy saving attitudes, behaviors and beliefs according to gender

\begin{tabular}{cccccccc}
\hline & Gender & $\mathrm{N}$ & $\overline{\mathrm{x}}$ & $\mathrm{SS}$ & $\mathrm{df}$ & $\mathrm{t}$ & $\mathrm{p}$ \\
\hline \multirow{2}{*}{ Attitude } & Female & 43 & 45.51 & 6.36 & 96 & 1.587 & 0.116 \\
& Male & 55 & 43.16 & 7.90 & & & \\
Behavior & $\mathrm{F}$ & 43 & 34.93 & 7.08 & 96 & 1.182 & 0.240 \\
& $\mathrm{M}$ & 55 & 36.61 & 6.96 & & & \\
Belief & $\mathrm{F}$ & 43 & 54.88 & 5.65 & 96 & 2.231 & $0.036^{*}$ \\
& $\mathrm{M}$ & 55 & 51.63 & 8.69 & & & \\
\hline
\end{tabular}

$* \mathrm{p}<0.05$

Table 2 shows that the average score related to the female students' attitudes was $\bar{x}=45.51$, while for the male students the average score was $\bar{x}=43.16$. Looking at the t-test results, no significant difference could be seen between the female and male students' water and energy saving attitudes $\left(\mathrm{t}_{(96)}=1.587 ; \mathrm{p}>0.05\right)$. The average behavior scores of the students according to gender were $\bar{x}=34.93$ for female students and $\bar{x}=36.61$ for male students. The t-test results indicate that the behavior scores of the students did not significantly differ according to

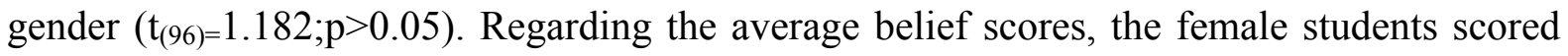
$\bar{x}=54.88$, while the male students scored $\bar{x}=51.63$. Results from the t-test found there to be a significant difference between students' belief scores according to gender, in favor of the female students $\left(\mathrm{t}_{(96)}=2.231 ; \mathrm{p}<0.05\right)$.

Table 3 below presents ANOVA results regarding high school students' water and energy saving attitudes, behaviors and beliefs in terms of grade level. 
Table 3. ANOVA Results associated with high school students' water and energy saving attitudes, behaviors and beliefs according to grade level

\begin{tabular}{|c|c|c|c|c|c|c|c|}
\hline & & $\begin{array}{l}\text { Sum of } \\
\text { Squares }\end{array}$ & $\mathrm{df}$ & $\begin{array}{l}\text { Mean } \\
\text { Square }\end{array}$ & $\mathrm{F}$ & $\mathrm{p}$ & Scheffe \\
\hline \multirow[t]{3}{*}{ Attitude } & Within group & 21.295 & 2 & 10.648 & .212 & .809 & \\
\hline & $\begin{array}{l}\text { Between } \\
\text { groups }\end{array}$ & 4773.236 & 95 & 50.245 & & & \\
\hline & Total & 4794.531 & 97 & & & & \\
\hline \multirow[t]{3}{*}{ Behavior } & Within group & 71.205 & 2 & 35.602 & .659 & .520 & \\
\hline & $\begin{array}{l}\text { Between } \\
\text { groups }\end{array}$ & 5136.112 & 95 & 54.064 & & & \\
\hline & Total & 5207.316 & 97 & & & & \\
\hline \multirow[t]{3}{*}{ Belief } & Within group & 386.681 & 2 & 193.340 & 3.469 & $.035^{*}$ & $9-11$ \\
\hline & $\begin{array}{l}\text { Between } \\
\text { groups }\end{array}$ & 5294.952 & 95 & 55.736 & & & \\
\hline & Total & 5681.633 & 97 & & & & \\
\hline
\end{tabular}

Table 3 shows that the students' scores on attitude and behavior toward water and energy saving did not significantly differ in terms of grade levels ( $F$ attitude $(2-95)=0.212 ; p>0.05 ; \mathrm{F}$

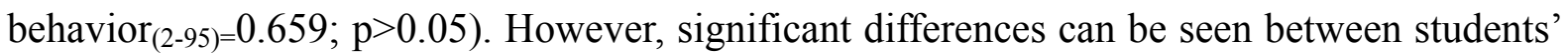
belief scores in the $9^{\text {th }}$ and $11^{\text {th }}$ grades, in favor of $9^{\text {th }}$ grade students $\left.\left(F_{(2-95}\right)=3.469 ; p<0.05\right)$.

Table 4 below presents the t-test results regarding high school students' water and energy saving attitudes, behaviors and beliefs in terms of whether or not they have membership in environment clubs.

Table 4. T-test results associated with high school students' water and energy saving attitudes, behaviors and beliefs according to membership in environment clubs

\begin{tabular}{cccccccc}
\hline \multirow{5}{*}{$\begin{array}{c}\text { Environment } \\
\text { Club }\end{array}$} & $\mathrm{N}$ & $\overline{\mathrm{x}}$ & $\mathrm{SS}$ & $\mathrm{df}$ & $\mathrm{t}$ & $\mathrm{p}$ \\
\hline \multirow{2}{*}{ Attitude } & Yes & 11 & 43.36 & 8.39 & 99 & 0.432 & 0.666 \\
& No & 90 & 44.36 & 7.12 & & & \\
\multirow{3}{*}{ Behavior } & Yes & 11 & 36.81 & 8.44 & 98 & 0.439 & 0.621 \\
& No & 89 & 35.80 & 6.82 & & & \\
Belief & Yes & 11 & 52.45 & 9.93 & 99 & 0.196 & 0.845 \\
& No & 90 & 52.93 & 7.35 & 99 & & \\
\hline
\end{tabular}

In Table 4, it can be seen that students with membership in environment clubs had an average attitude score of $\bar{x}=43.36$, while students without membership had an average attitude score of $\bar{x}=44.36$. The t-test results show that students' attitude scores did not significantly differ 
according to membership in environment clubs $\left(t_{(99)}=0.431 ; p>0.05\right)$. The average behavior score of students with membership in environment clubs was $\bar{x}=36.81$, whereas the same score for students without membership was $\bar{x}=35.80$. T-test results reveal that students' behavior scores did not significantly differ according to this variable $\left(t_{t(98)}=0.439 ; p>0.05\right)$. Looking at the students' belief scores, students with environment club membership were found to have an average score of $\bar{x}=52.45$, while students without a membership had an average of $\bar{x}=52.93$. T test results indicate that students' belief scores did not significantly differ according to this variable $\left(\mathrm{t}_{(99)}=0.845 ; \mathrm{p}>0.05\right)$.

Table 5 below presents the t-test results regarding high school students' water and energy saving attitudes, behaviors and beliefs in terms of their families' environmental awareness.

Table 5. T-test results associated with high school students' water and energy saving attitudes, behaviors and beliefs according to their families' environmental awareness

\begin{tabular}{cccccccc}
\hline \multirow{2}{*}{ Attitude } & Family & $\mathrm{N}$ & $\overline{\mathrm{x}}$ & $\mathrm{SS}$ & $\mathrm{df}$ & $\mathrm{t}$ & $\mathrm{p}$ \\
& Yes & 82 & 45.51 & 6.84 & 99 & 3.867 & $0.00^{* *}$ \\
& No & 19 & 38.84 & 6.45 & & & \\
Behavior & Yes & 81 & 36.01 & 6.64 & & & \\
& No & 19 & 35.05 & 8.45 & 98 & 0.537 & 0.592 \\
& Yes & 82 & 54.03 & 6.94 & & & \\
& No & 19 & 47.89 & 8.53 & 99 & 3.322 & $0.00^{* *}$ \\
\hline
\end{tabular}

$* * \mathrm{p}<0.00$

Table 5 indicates that the average attitude score of students with an environmentally aware family member was $\bar{x}=45.51$, while that of students without an environmentally aware family member was $\bar{x}=38.44$. Results from the t-test show that students' attitude scores significantly differed according to whether or not the student had an environmentally aware family

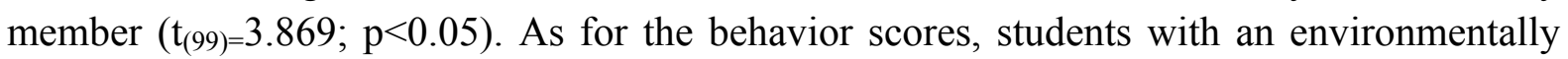
aware family member had an average score of $\bar{x}=36.01$, while students without an environmentally aware family member had an average score of $\bar{x}=35.05$. T-test results reveal no significant difference between students' behavior scores according to this variable $\left.\mathrm{t}_{\mathrm{t}(98)}=0.439 ; \mathrm{p}>0.05\right)$. Students with an environmentally aware family member had an average belief score of $\bar{x}=54.03$, while those without had an average of $\bar{x}=47.89$. T-test results indicate a significant difference between students' belief scores according to this variable $\left(_{t(99)=3.332}\right.$; $\mathrm{p}<0.05)$.

Table 6 below presents the ANOVA results regarding high school students' water and energy saving attitudes, behaviors and beliefs in terms of level of concern about environment. 


\section{IIMacrothink}

International Journal of Education

ISSN 1948-5476

2016, Vol. 8, No. 2

Table 6. ANOVA results associated with high school students' water and energy saving attitudes, behaviors and beliefs according to level of concern about the environment

\begin{tabular}{|c|c|c|c|c|c|c|c|}
\hline & & $\begin{array}{l}\text { Sum of } \\
\text { Squares }\end{array}$ & df & $\begin{array}{c}\text { Mean } \\
\text { Square }\end{array}$ & $\mathrm{F}$ & $\mathrm{p}$ & Scheffe \\
\hline \multirow{5}{*}{ Attitude } & & & & & & & Very \\
\hline & Between groups & 616.051 & 4 & 154.013 & 3.205 & .016 & Low-Very \\
\hline & & & & & & & High \\
\hline & Within group & 4613.256 & 96 & 48.055 & & & \\
\hline & Total & 5229.307 & 100 & & & & \\
\hline \multirow{3}{*}{ Behavior } & Between groups & 38.677 & 4 & 9.669 & .192 & .942 & \\
\hline & Within group & 4791.433 & 95 & 50.436 & & & \\
\hline & Total & 4830.110 & 99 & & & & \\
\hline \multirow{6}{*}{ Belief } & & & & & & & Very \\
\hline & & & & & & & m, very \\
\hline & Between groups & 1167.701 & 4 & 291.925 & 6.047 & .000 & $\begin{array}{c}\text { low high, } \\
\text { very }\end{array}$ \\
\hline & & & & & & & $\begin{array}{c}\text { low-very } \\
\text { high }\end{array}$ \\
\hline & Within group & 4634.873 & 96 & 48.280 & & & \\
\hline & Total & 5802.574 & 100 & & & & \\
\hline
\end{tabular}

Table 6 indicates that students' attitudes toward water and energy saving significantly differed in terms of their level of concern about the environment $\left(F_{(4-96)}=3.205 ; p<0.05\right)$. The Scheffe test results reveal the attitude score difference between the students with the lowest level of concern and the students with the highest level of concern. The results associated with behaviors did not indicate any significant difference between the students' scores $\left(\mathrm{F}_{(4-96)}=0.192 ; \mathrm{p}>0.05\right)$. In contrast, the results associated with belief show a significant difference between students' belief scores according to their level of concern about the environment $\left(\mathrm{F}_{(4-96)}=6.047 ; \mathrm{p}<0.05\right)$. Scheffe test results indicate that this difference is most pronounced between students with very low-mid, very low- high and very low-very high levels of concern about the environment.

Table 7 below presents the correlation results regarding high school students' water and energy saving attitudes, behaviors and beliefs. 
Table 7. Correlation results associated with high school students' water and energy saving attitudes, behaviors and beliefs

\begin{tabular}{rlrrr}
\hline & & Attitude & Behavior & Belief \\
\hline Attitude & $\mathrm{r}$ & 1 & .170 & $.479^{* *}$ \\
& $\mathrm{p}$ & & .092 & .000 \\
& $\mathrm{~N}$ & 101 & 100 & 101 \\
Behavior & $\mathrm{r}$ & .170 & 1 & .073 \\
& $\mathrm{p}$ & .092 & & .471 \\
& $\mathrm{~N}$ & 100 & 100 & 100 \\
Belief & $\mathrm{r}$ & $.479^{* *}$ & .073 & 1 \\
& $\mathrm{p}$ & .000 & .471 & \\
& $\mathrm{~N}$ & 101 & 100 & 101 \\
\hline
\end{tabular}

Table 7 shows a mid-level significant relationship between students' attitude and belief scores $(\mathrm{r}=0.479 ; \mathrm{p}<0.05)$, although no significant relationship was found between high school students' attitude and behavior $(\mathrm{r}=0.170 ; \mathrm{p}>0.05)$ and behavior and belief scores in relation to water and energy saving $(\mathrm{r}=0.173 ; \mathrm{p}>0.05)$.

\section{Discussion, Conclusion and Suggestions}

To briefly summarize, the research results demonstrated that high school students' attitudes toward water and energy saving were at a high level, their behaviors were at a mid-to-high level and their beliefs were at a high-to-very-high level. DeWaters and Powers (2011) showed in their study that middle school students had positive attitudes toward saving energy.

When the results from the study are considered in terms of gender, no significant differences were observed among the female students' attitudes and behaviors toward saving water and energy. In other words, gender did not significantly predict students' attitudes and beliefs. The results associated with belief showed that female students had significantly more positive beliefs about saving water and energy than their male counterparts. Furthermore, it was found that female students had significantly stronger attitudes toward energy saving than the male students (Barrow and Morrisey, 1987; Lawrenz and Dantchik, 1985; Clewell and Cambell, 2002). In agreement with these results, the findings from the study by Barrow and Morrisey (1987) demonstrated that female students' attitudes toward energy were at higher levels than those of male students.

The findings related to grade level showed that this variable had no significant impact on students' attitudes toward saving water and energy. In terms of belief however, a significant difference was found between the $9^{\text {th }}$ and $10^{\text {th }}$ grade students' scores. It can, therefore, be said that grade level is a significant predictor of students' beliefs about saving water and energy. Atasoy and Erturk (2008) likewise showed grade level to be a significant factor in students' attitudes toward the environment. 
Only a few students had memberships in environment clubs. When the results were analyzed in terms of membership in environment clubs, no significant differences were observed in students' attitudes and behaviors toward and beliefs about saving water and energy among those who were members of an environment club versus those who were not. Otherwise stated, students' membership in an environment club is not a predictor of their attitudes and behaviors toward and beliefs about water and energy saving. Nancarrow et al., (1996) stated in their study that formulation of thoughts about water in general had no relationship with water conservation.

The role of the family is an important component of environment education. Having environmentally aware members in the family was shown to be a significant factor in forming students' attitudes and beliefs about saving water and energy. One of the more notable findings in the current research is that students with environmentally aware family members exhibited more positive attitudes toward and beliefs about saving water and energy. This result can be interpreted to mean that a positive relationship exists between the presence of family members who think about and discuss environmental issues at home and the development of greater awareness of the environment. In one study it was found that students who discussed energy issues with family members at home demonstrated greater awareness about saving energy (DeWaters and Powers, 2011). Furthermore, many studies have shown that energy saving is associated with people's life styles (Nakagami, 1996; Bin and Dowlatabadi, 2005). The motivation to save water is one of the significant predictors of water saving behaviors. People who talk about the topic of water saving at home and participate in activities related to this topic tend to actually save more water (Corral-Verdugo, 2002).

No significant difference was observed between students' behaviors toward saving water and energy according to concern level about the environment; however, their attitudes and beliefs differed significantly in terms of this variable. It was found that students with higher levels of concern about the environment had more positive attitudes and beliefs than students with lower levels of concern about the environment. This result indicates that the thinking, worrying about and being interested in the environment fostered positive attitudes toward and beliefs about saving water and energy. Numerous studies have shown that interest in water conservation is a significant factor in water saving behavior (Middlestadt et al., 2001; CSIRO, 2002).

When considering the relationships between students' attitudes and behaviors toward and beliefs about saving water and energy, no significant relationships between attitude and behavior and attitude and belief were defined; however, a mid-level significant positive relationship between belief and attitude was found. This finding can be interpreted to mean that as students' adopt healthier attitudes toward saving water and energy, they develop stronger beliefs about saving water and energy. Although Nancarrow et al., (1996) found there to be no relationship between general interest in water conservation and actually saving water, other studies have defined a relationship between interest in environment and saving water (Corral-Verdugo et al., 2003).

To conclude, high school students were shown to have high-level attitudes toward and beliefs 
about saving water and energy and mid-level saving behaviors. In other words, the students' high-level attitudes toward and beliefs about saving water and energy are not reflected in their behaviors. The study has shown that many variables influence students' beliefs about saving water and energy, including gender, grade level, environmentally aware members in the family and concern for the environment.

Based on the research results, the following suggestions are made:

Given that male students had lower-level attitudes toward and beliefs about saving water and energy, future studies should focus on exploring the reasons for this.

Considering the students' mid-level water and energy saving behaviors, environmental education programs should be implemented in order to raise these to higher levels.

As it was observed that students with environmentally aware family members had more sensitivity towards saving water and energy, the inclusion of families in environment education programs should serve to increase the effectiveness of those programs.

And lastly, with the concern level towards environment being a significant predictor of students' attitudes toward and beliefs about saving water and energy, activities directed towards increasing students' concern levels for the environment should be included in environment classes and environment education programs.

\section{References}

Aijami, M.F. (2008). Water conservation knowledge and behaviors of basic college of education in kuwatt. University of Arkansas. Doctoral Dissertation.

Alaş, A., Tunç H., Kışoğlu, M., \& Gürbüz, T. (2009). An investigation on prospective teachers'conscious water consumption: Atatürk university sample. Journal of Erzincan Education Faculty, 11(2), 37-49.

Algül E (2004). Çevre sorununda çağdaş yaklaşım ve stratejiler-1, çevre sorununda Türkiye için çevre politikaları. Retrieved from http://evrenselgercekler.blogcu.com/cevre-sorununda-cagdas-yaklasim-vestratejiler-1/19 80208

Atasoy, E., \& Ertürk, H. (2008). İlköğretim öğrencilerinin çevresel tutum ve çevre bilgisi üzerine bir alan araştırması [A field study about environmental knowledge and attidudes of elementary school students] Erzincan Eğitim Fakültesi Dergisi, 10(1), 105-122

Attari, S.Z., DeKay, M.L., Davidson, C.I., \& Bruine de Bruin, W. (2010). Public perceptions of energy consumption and savings. In Proceedings of the National Academy of Sciences, 107(37), 16054-16059.

Aydıner Boylu, A., \& Yertutan, C. (2012). Erkeklerin evde enerji ve su tasarrufu konusundaki alışkanlık ve satın alma odaklı davranışlarının incelenmesi. Sosyo Ekonomi, (1), 156-171. 
Barrow, L.H., \& Morrisey, J.T. (1989). Energy literacy of ninth-grade students: A comparison between Maine and New Brunswick. Journal of Environmental Education, 20, 22-25. http://dx.doi.org/10.1080/00958964.1989.9943027

Bin, S., \& Dowlatabadi, H. (2005). Consumer lifestyle approach to US energy use and the related $\mathrm{CO}_{2}$ emissions. Energy Policy, 33, 197-208. http://dx.doi.org/10.1016/S0301-4215(03)00210-6

Clewell, B. C., \& Campbell, P. B. (2002). Taking stock: where we've been, where we are, where we're going. Journal of Women and Minorities in Science and Engineering, 8, 255-284.

Corral-Verdugo, V., \& Armendáriz, L.I. (2000). The "New Environmental Paradigm" in a Mexican community. Journal of Environmental Education, 31, 25-31. http://dx.doi.org/10.1080/00958960009598642

CSIRO (2002). Perth domestic water-use study household ownership and community attitudinal analysis NSW, Australian Research Centre for Water in Society CSIRO Land and Water

Curry, T.E., Ansolabehere, S., \& Herzon, H. (2007). A survey of public attitudes towards climate change and climate change mitigation technologies in the United States: Analyses of 2006 results. MIT LFEE 2007-01.

Çankaya, C., \& Çelik İşcen, C. (2014). Fen bilgisi öğretmen adaylarına yönelik su tüketim davranış ölçeği: geçerlik ve güvenirlik çalışması. E-Journal of New World Sciences Academy, 9(3), 341-352.

Demir, M. (2009). İlköğretim ikinci kademe öğrencilerinde su bilinci. Yüksek Lisans Tezi. Kafkas Üniversitesi, Kars.

Dewaters, J.E., \& Powers, S.E. (2011). Energy literacy of secondary students in New York State (USA): A measure of knowledge, affect, and behavior. Energy Policy, 39(3), 1699-1710.

Doğan, M., (1997). “Çevre Eğitimi”, Çevre ve İnsan, Mart.

EIA, (2009). Energy Information Administration (EIA), 2009. State renewable energy requirements and goals: update through, 2008.

Gambro, J.S., \& Switzky, H.N. (1999). Variables associated with American high school students' knowledge of environmental issues related to energy and pollution. Journal of Environmental Education, 30(2), 15-22. http://dx.doi.org/10.1080/00958969909601866

Gardner, G.T., \& Stern, P.C. (2008). The short list: The most effective actions U.S. households can take to curb climate change. Environment Magazine, 50, 12-24.

Godfray, H. C. J., Beddington, J. R., Crute, I. R., Haddad, L., Lawrence, D., Muir, J. F., \& Toulmin, C. (2010). Food security: the challenge of feeding 9 billion people. Science, 327(5967), 812-818. 
Hancher, L., \& Janssen, S. (2004). Shared Competences and Multi-Faceted Concepts European Legal Framework for Security of Supply. In B. Barton, C. Redgwell, A. Ronne, and D.N. Zillman (eds.) Energy Security: Managing Risk in a Dynamic Legal and Regulatory Environment. Oxford: Oxford University Press, pp. 85 - 119.

Hansen, J. (2009). Storms of my grandchildren. USA: Bloomsbury

Mankoff, J., Susan R. Fussell, Tawanna Dillahunt, Rachel Glaves, Catherine Grevet, Michael Johnson, Deanna Matthews, H. Scott Matthews, Robert McGuire, Robert Thompson, Aubrey Shick, Leslie Setlock. Increasing energy saving behaviors via social networks. Proceedings of the Fourth International AAAI Conference on Weblogs and Social Media.

Jury, W.A., \& Vaux, H. Jr. (2005). The role of science in solving the world's emerging water problems. Proceedings of the National Academy of Sceinces of the United States of America, 102(44), 15715-15720.

Karasar, N. (1999). Bilimsel araştırma yöntemi. Ankara: Nobel Yayın Dağıtım Ltd. Şti.E.

Lawerenz, F., \& Dantchik, A. (1985). Attitudes toward energy among students in grades 4, 7, and high school. School Science and Mathematics, 85(3), 189-202. http://dx.doi.org/10.1111/j.1949-8594.1985.tb09612.x

Lawrenz, F. (1983). Student knowledge of energy issues. School Science and Mathematics, 83(7), 587-595. http://dx.doi.org/10.1111/j.1949-8594.1983.tb10142.x

Middlestadt, S., Grieser, M., Hernandez, O., Tubaishat, K., Sanchack, J., Southwell, B., \& Schwartz, R. (2001). Turning Minds on and Faucets off: water conservation education in Jordanian Schools. The Journal of Environmental Education, 32(2), 37-45

Nakagami, H. (1996). Lifestyle change and energy use in Japan: Household equipment and energy consumption. Energy, 21(12), 1157-1167.

Nancarrow, B. E., Smith, L. M., \& Syme, G. J. (1996). The ways people think about water. Journal of Environmental Systems, 25(1).

Population Institute. (2013) Retrieved from http://www.populationinstitute.org/

Rogers, P. (2008). Facing the Freshwater Crisis, Scientific American, 299, pp.46-53

Turan, T., \& Eren, Z. (2008). Türkiye'de su kaynakları ve su politikası. TMOOB 2. Su Politikaları Kongresi Bildiriler Kitabı, 1, 25-32.

United Nations Environment Programme [UNEP] (2002). Vital Water Graphics. Retrieved from http://www.unep.org./dewa/assessments/ecosystems/water/vitalwater/fres hwater.htm

Weber, C., \& Matthews. (2007). H.S. Embodied environmental emissions in US international trade 1997-2004. Environmental Science and Technology, 41, 4875-4881. 


\section{Macrothink}

Endnote: This study was orally presented at the Ufbmek2014 Conference.

\section{Copyright Disclaimer}

Copyright for this article is retained by the author(s), with first publication rights granted to the journal.

This is an open-access article distributed under the terms and conditions of the Creative Commons Attribution license (http://creativecommons.org/licenses/by/3.0/). 